\title{
ОЖИРІННЯ ЯК НАСЛІДОК ЦУКРОВОЇ ЗАЛЕЖНОСТІ У ДІТЕЙ
}

\author{
К. О. Надточий \\ ДВНЗ «Тернопільський державний медичний університет \\ імені І. Я. Горбачевського МОЗ Украӥни»
}

У статті проаналізовано взаємозв’язок між вживанням доданих цукрів та проблемою ожиріння у дітей.

\section{OBESITY AS AN IMPACT OF SUGAR ADDICTION IN CHILDREN}

\author{
K. O. Nadtochiy
}

\section{Horbachevsky Ternopil State Medical University}

The article represents the analysis of association between the added sugars and the obesity problem in children.

Вступ. Ожиріння - це захворювання, що характеризується накопиченням надлишкової маси тіла у зв'язку з надмірним відкладенням жирової тканини. Медики всього світу визнають ожиріння епідемією XXI століття. Надлишкова маса тіла, ожиріння - це величезна проблема не лише для пацієнтів, але й для лікарів усіх спеціальностей, оскільки саме ця кількість людей входить в групу підвищеного ризику щодо розвитку безлічі захворювань, перше місце серед яких займають хвороби серцево-судинної системи. На жаль, з кожним днем зростає і кількість дітей, у яких із раннього віку розвивається ця недуга.

За останні десятиріччя проблема зайвої ваги та ожиріння стала глобальною, і поширилася на жителів країн навіть з низьким рівнем життя. За даними ВОО3, у 2005 р. надлишкову масу тіла мали приблизно 1,6 млрд дорослих у світі, і як мінімум у 400 млн із них діагностували ожиріння. До 2015 р. ці цифри зросли, відповідно, до 2,3 млрд і 700 млн [1, 3].

Станом на 2016 р. ожиріння в Україні діагностували у $26 \%$ жінок і 16 \% чоловіків, а надлишкову масу тіла мають 40 \% населення країни [2]. Офіційних даних щодо ожиріння у дітей за останні роки немає. Однак, за даними ВОО3, за 2015 р. у нашій країні надлишкову масу тіла мали 25 \% дітей, а це кожна четверта дитина. Тобто, в Україні щорічно фіксують 18 000-20 000 нових випадків ожиріння серед дітей та підлітків. якщо говорити про інші країни для порівняння, то в Німеччині число дітей з ожирінням становить $30 \%$, а в Британії - $27 \%$ [2, 3].

(с) К. О. Надточий, 2018
Статистика свідчить про те, що надлишкова маса тіла практично завжди призводить до розвитку цукрового діабету, артеріальної гіпертензії, ішемічної хвороби серця, інсульту, дискінезій жовчного міхура, жовчнокам'яної хвороби, хронічного холециститу, безпліддя, остеохондрозу хребта і обмінно-дистрофічних поліартритів, деяких видів раку та інше. Щорічно, від пов'язаних із ожирінням захворювань, у всьому світі помирають понад 400 тис. людей, тому ця проблема з кожним роком привертає все більшу увагу світової спільноти [4].

Основна частина. Ожиріння дітей діагностується як хронічне рецидивне захворювання, що проявляється надлишковим накопиченням жирової тканини і $є$ дисбалансом надходження і витрат енергії в організмі дітей зі спадковою схильністю чи без неї [4].

Існують різні методи оцінки здорової маси тіла залежно від віку, при цьому вибрати якийсь один показник складно, оскільки організм дитини росте, відбуваються фізіологічні зміни. Найпоширенішим критерієм надлишкової маси тіла та ожиріння $є$ індекс маси тіла (IMT), який визначається як відношення показника маси тіла (в кілограмах) до показника зросту (в метрах в квадраті (кг/м²)). Ожиріння констатується при збільшенні маси тіла за рахунок жирової тканини, підвищенні ІМТ для даного зросту, маси, віку, статі. За сучасними рекомендаціями, ліпідний скринінг слід проводити дітям з ІМТ від 80 перцентиля, а не 85, при якому вже діагностують надлишкову масу тіла у дітей. Варто зазначити, що ожиріння в дитинстві - це підвищений ризик ожиріння в дорослому віці. Так, діти до 
12 років з ожирінням у 80-90 \% випадків мають ожиріння у зрілому віці, і, на жаль, в подальшому спроби наблизити масу тіла до нормальних показників часто залишаються невдалими [5].

Одним із найвпливовіших факторів ризикущодо розвитку ожиріння в дитячому віці $є$ залежність від цукру, цукровмісних продуктів. В основному це стосується прихованого цукру в кондитерських, молочних продуктах, кетчупах, соусах, соках, мюслі, і навіть в дитячому харчуванні. Тому дуже цікавими виявились результати досліджень з вивчення взаємозв'язку між особливостями харчування дитини та динамікою маси, що підтвердили зростання показника IMT у цій групі дітей [2].

Надлишкова маса тіла насамперед асоціюється 3 вживанням напоїв, що містять додаткові цукри, і відсутністю при цьому відчуття ситості, що є причиною неконтрольованого споживання їжі. Так, в одному із досліджень, спостерігали за динамікою маси тіла дітей віком 4-12 років, які впродовж 18 місяців щоденно вживали підсолоджений напій, калорійністю 104 ккал. Результати спостереження підтвердили, що вживання штучних цукровмісних напоїв призводить до збільшення маси тіла. Водночас на сьогодні немає переконливих даних, які 6 свідчили про зниження маси тіла при вживанні низькокалорійних напоїв [6].

Упродовж останніх декад суттєво збільшилося вживання цукровмісних продуктів у всьому світі. Підсолоджені напої є одним із найбільших джерел додаткового цукру, надмірного метаболізму фруктози, що призводять до розвитку запальних змін, послаблення функції бета-клітин підшлункової залози, інсулінорезистентності, артеріальної гіпертензії, накопичення вісцерального жиру, формування атерогенної дисліпідемії, тим самим збільшують ризик виникнення цукрового діабету 2 типу, кардіоваскулярної патології. Водночас цукровмісні напої мають мізерну поживну цінність. Зважаючи на усе це, вживання їх необхідно обмежити та замінити здоровою альтернативою, наприклад водою.

З дитинства у багатьох дітей під впливом поведінки дорослих та засобів масової інформації формується патологічне сприйняття споживання солодощів як винагороди, заохочення, турботи чи навіть як прояв любові до них. Сенс цієї «винагороди їжею» закладає мотивацію до споживання все більшої кількості цукру протягом життя. На сьогодні вже доведено, що при підвищенні рівня цукру в організмі внаслідок споживання підсолоджених продуктів, мозок дитини з ожирінням активно реагує на подразнення в тих ділянках, які залучені в процеси сприйняття, в емоційні реакції, в усвідомлення самого себе, а також зони смаку, мотивації та винагороди. І порівняно із здоровими дітьми, у дітей із ожирінням така відповідь мозку прослідковується більш виразно [8].

Тому ще однією з причин розвитку ожиріння від цукрової залежності $\epsilon$ психологічний комфорт, що виникає у відповідь на вплив цукру на мозок. До психологічної зони впливу цукрової залежності на ожиріння можна також віднести збільшену продукцію позаклітинного дофаміну, що виникає з відчуттям надмірної насолоди від солодощів та смачної їжі, і тим самим, збільшує адиктивний потенціал цукру. Водночас виявлено декілька подібностей між цукровою та наркотичною залежністю, включаючи патологічну потребу, втрату контролю [9].

у західних країнах багато уваги приділяють вивченню прихованого впливу фруктози на розвиток ожиріння. За смаковими властивостями фруктоза значно солодша від сахарози і глюкози. Фруктоза не піднімає рівень цукру в крові та засвоюється без участі гормону інсуліну. Зважаючи на такі особливості, хворі на цукровий діабет використовують фруктозу, тому і виник міф про їі корисні властивості й для здорових людей. Але насправді це не так [10].

На відміну від глюкози, що слугує універсальним джерелом енергії, фруктоза всмоктується із травного тракту лише шляхом пасивної дифузії, майже повністю поглинається клітинами печінки. Практично всі інші клітини людського організму не використовують фруктозу. В клітинах печінки фруктоза перетворюється безпосередньо у вільні жирні кислоти, тобто жир, що, в свою чергу, призводить до ожиріння і розвитку серцево-судинних захворювань.

За результатами численних досліджень доведено, що фруктоза не стимулює вироблення двох найважливіших гормонів, що беруть участь в довготривалому процесі регулювання енергетичного балансу організму - інсуліну та лептину. На відміну від глюкози, вона не сприяє виділенню інсуліну підшлунковою залозою. І якщо невисокі дози фруктози можуть бути рекомендовані для хворих на цукровий діабет 2 типу, то для людей, які намагаються позбавитися зайвої маси, іï використання $\epsilon$ вкрай небажаним. Адже, інсулін впливає на процес регулювання кількості жиру, сповільнюючи засвоєння їжі та збільшує витрати енергії. Його виділення відбувається після їжі як реакція на спожиті вуглеводи. Але окрім супроводу глюкози до клітин тіла, інсулін ще виконує функцію індикатора, що показує, скільки їжі спожито, і коли потрібно зупинитися. Якщо інсулін не виділяється - механізм, що контролює процес надходження енергії, відсутній. 
У цьому випадку, організм починає набирати зайву масу, що й призводить до ожиріння [10].

Висновки. На жаль, в Україні, як і в усьому світі, проблема надмірного споживання цукру із взаємопов'язаним збільшенням маси тіла серед дитячого та дорослого населення так і залишається невирішеною. Однією з причин неухильного зростання рівня ожиріння $\epsilon$ несвідоме надмірне споживанням цукру, що приховано міститься в багатьох продуктах щоденного харчування та напоях.

Саме тому, ВООЗ рекомендує знижувати кількість споживання цукру до рівня нижче 10 \% від загальної кількості добових калорій, з тенденцією цільового зниження до рівня 5 \%, адже вважається, що такий ліміт допоможе стримати зростання рівня ожиріння $[3,11]$.

Хоча такий 5 \% рекомендований ліміт знаходиться нижче, ніж поточний рівень споживання цукру, особливо дітьми, варто зазначити, що в Україні все більше привертають увагу до цієї проблеми, а також здійснюють кроки для більшого контролю над си-

\section{СПИСОК ЛІТЕРАТУРИ}

1. Большова О. В. Ожиріння в дитячому та підлітковому віці [Електронний ресурс] / О. В. Большова // Здоров'я України: медична газета. - 2008. - № 18/1, червень. С. 50-53. - Режим доступу: <https://www.srasanz.org/sras/ sugar-and-health/sugar-and-obesity/>.

2. Абрамова Ю. Любите сладкое: как побороть зависимость? [Электронный ресурс] / Ю. Абрамова // 2017. - 2 квітня. - Режим доступа : <http://www.likar.info/ zdorovoe_pitanie_i_dieti/news-79085-lyubite-sladkoe-kakpoborot-zavisimost/>.

3. World Health Organisation, 2015. Obesity and Overweight. [Electronic source]. Mode access: http://www. who.int/mediacentre/factsheets/fs311/en/.

4. Горобей М. П. Проблеми надлишкової ваги та ожиріння школярів і студентів / М. П. Горобей // Педагогіка, психологія та медико-біологічні проблеми фізичного виховання і спорту : зб. наук. пр. ; за ред. С. С. Єрмакова. Харків : ХДАДМ, 2012. - № 5. - С. 47-49.

5. Sugar sweetened beverages, obesity, type 2 diabetes and cardiovascular disease risk / V. S. Malik, B. M. Popkin, G.A. Bray [et al.] // Circulation. - 2010. - Vol. 23; 121 (11). P. 1356-1364. Mode access : https://www.ncbi.nlm.nih.gov/ pmc/articles/PMC2862465.

6. Trial of sugar-free or sugar-sweetened beverages and body, weight in children / J. C. de Ruyter, M. R. Olthof, J. C. Seidell [et al.]. Mode access: http://www.nejm.org/doi/ full/10.1056/NEJMoa1203034. туацією. Так все більше авторитетних дослідників із дієтології піднімають це питання на рівні суспільства та проводять роз'яснювальну роботу за допомогою засобів масової інформації [12].

Також розроблено «Довідникові дані з розвитку» дітей і молодих людей віком 5-19 років, що основані на показниках Національного центру медико-санітарної статистики ВООЗ, доповнені даними із «Стандартних показників ВООЗ у галузі розвитку дитини» для дітей раннього віку до 5 років. У свою чергу, дані довідники основані на оглядах наукових свідчень щодо впливу цукру на здоров'я людини [3, 11].

І врешті, важливо відзначити, що на сьогодні в Україні розроблено та впроваджено в практику рекомендації щодо зниження споживання цукровмісних продуктів, затверджено норми фізіологічних потреб в основних харчових речовинах, що відображено в нормативних документах. Це дає надію на активне впровадження в життя принципів здорового харчування [13].

7. Sugar addiction and obesity starts in childhood // Health \& Nutrition, Parenting. Mode access: http://blog. neurogistics.com/index.php/sugar-addiction-and-obesitystarts-in-childhood.

8. Fortuna J. L. The obesity epidemic and food addiction: Clinical similarities to drug dependence / J. L. Fortuna // Journal of Psychoactive Drugs. - Vol. 44, Iss. 1. - 2012. Mode access: http://www.tandfonline.com/doi/abs/10.1080/0279 1072.2012.662092.

9. The Sugar Research Advisory Service [Electronic source]. Mode access: https://www.srasanz.org/sras/sugar-andhealth/sugar-and-obesity/.

10. Фруктоза, сахароза, глюкоза [Електронний ресурс]. 2015. - 27 жовтня. - Режим доступу : <https://do4a.com/ threads/Фруктоза-Сахароза-Глюкоза.20869/>.

11. Briggs H. WHO: Daily sugar intake should be halved / H. Briggs // BBC News. Mode access: http://www.bbc.com/ news/health-26449497.

12. Дієтологія / за ред. Н. В. Харченко, Г. А. Анохіної. - К. , 2012. - 526 c.

13. Про затвердження норм фізіологічних потреб населення України в основних харчових речовинах і енергії [Електронний ресурс] : наказ МОЗУкраїни від 03.09.2017 р. № 1073. - Режим доступу : <http://zakon2.rada.gov.ua/laws/ show/z1206-17>. 